\title{
Educational Technology for Teaching and Learning in the Post Covid-19 Era: A Case Study of Tertiary Institutions in Imo State, Nigeria
}

\author{
Ojukwu, Njideka-Nwawih Charlotte ${ }^{1}$, Agim Eliezer Chukwuyere ${ }^{2}$, \\ Ameh Catherine ${ }^{3}$ \\ ${ }^{1}$ Lecturer, Federal University Lokoja, Kogi State \\ ${ }^{2}$ Polytechnic Librarian, Sure Foundation Polytechnic, Ukanafun, Akwa Ibom State \\ ${ }^{3}$ Principal Lecturer, College of Education, Oju, Benue State \\ Corresponding Author: Agim Eliezer Chukwuyere
}

\section{ABSTRACT}

The research work was on educational technologies for teaching and learning in the post Covid 19 era: A case of tertiary institutions in Imo State. The study has 4 research questions. The study adopted survey research design. A sample population of 10 educators each was drawn from the department of Library and Information Science of Federal Polytechnic Nekede Owerri (FPNO) and Imo State University Owerri (IMSU). Observation checklist and questionnaire were used to collect data. Data collected were analyzed using frequencies, percentages and mean scores. The study found that the available educational technologies for teaching and learning in tertiary institutions in Imo State were computers, powerpoint equipment, social media tools, projectors, etc. The educational technologies integrated in teaching and learning in the post Covid 19 era are computers, whiteboards, smart boards, projectors, tablet or smartphone, digital cameras, etc. The challenges to the integration of educational technologies for teaching and learning are inadequate funding, insufficiency of ET/ICT infrastructure, erratic power supply, high cost of ET, and poor ICT policy in the use of ICT/ET etc. The solutions to the challenges in the integration of educational technologies for teaching and learning are adequate funding, sufficiency of ET/ICT infrastructure, good power supply, good maintenance culture on ET, adequate technical support, and regular training of educators in use of ET etc. The research concluded that the outburst of Covid 19
\end{abstract}

pandemic has provided educators with the opportunity to adopt educational technologies for teaching and learning in the post covid 19 era, and integrating these educational technologies in tertiary institutions will improve digital education and as well enable students to continue their learning activities. The study recommended that adequate training on the use of educational technologies should be provided for educators and their students to improve their teaching and learning, and that there should be adequacy of educational technological tools and resources to support teaching and learning activities in the post Covid 19 era

Keywords: Educators, Educational technologies, Teaching and learning, Tertiary institutions, Post Covid 19 era

\section{INTRODUCTION}

Covid 19 pandemic is a deadly disease. Coronavirus first appeared in the city of Wuhan, China, and has spread rapidly to almost all countries across the world (Agim, Oraekwe, Chivuzo \& Emenari, 2020). In light of the rising concerns about the spread of Covid 19 and its rate of infections across the globe, many educational institutions have shut down classes and physical contacts/sessions. The Corona virus has revealed emerging vulnerabilities in the education systems around the world (Ali, 2020). It is now clear on the need for a flexible and resilient 
educational system as we face unpredictable futures. Against the backdrop, various policy initiatives are being launched by governments and tertiary institutions across the world to map out a means that will enhance continuous teaching activities so as to contain the virus. However, as the world settles gradually towards the post Covid 19 pandemic era, there is anxiety on how to sustain the tempo in the use of related technology for classes and also in the event of a repeat of similar outbreak in the nearest future. This post Covid 19 pandemic era has brought about certain opinions about which system to use in teaching, how to use them to teach, the skills of teachers and students in using them for teaching and learning, and the availability of the system to be used for teaching and learning in tertiary institutions. These have lead to the view that the adoptions of educational technologies will be best suited to the post Covid 19 teaching and learning activities while also supporting remote learning; distance education and online learning in future.

Educational technologies otherwise known as educational equipment, audio or visual resources are learning media or systems that are used to project learning instructions to a wide group of people cutting across locations, usually connected to provide access to learners. These educational technologies can be personnel computer, connected computers, projectors, computer-based learning softwares, Moodle, LMS (Black board), PowerPoint, smart boards, whiteboard and some collaborative tools, such as Microsoft Groove and Dropbox, which are teaching assistance technology. Education Technology (ET) is defined as "the study and ethical practice of facilitating learning and improving performance by creating, using and managing appropriate technological processes and resources" (Richey, 2008). ET can be used by all educators who want to incorporate technology in their teaching as well as educational administrators. The emergence of different educational tools and software has motivated may learning organizations to integrate them into the curriculum as they can have a great impact on student learning (Hawkins, Panush \& Spielvogel, cited in AlAmmary, 2012).

In view of the forgoing, it is clear that these educational technologies can empower teachers and learners, promote change and foster the development of twenty-first century skills. Educational technologies can also enhance students' learning and achievement; provide motivation for them to get more involved in learning activities through which they become more active and more interested in learning even at the post Covid 19 pandemic era. According to Stošić (2015), the application of educational technology requires knowledge from several areas: pedagogy, psychology, didactics, computer sciences, informatics...(111). Therefore, the educator must be skilled in the use of Microsoft Groove and Dropbox which are teaching assistance technologies. The integration of these technologies can enhance their communication with the students; reduce the teaching pressure caused by the course material preparation. Aside integrating these educational technologies, Ngakan (2016) stated that educators need to be innovative and creative in their teaching methods so that the learning process will more interesting and can reach the target learning. This can be happen if the educator continues to update the teaching materials (educational technologies) with varied learning methods.

Notwithstanding the fact that integration of educational technologies are emerging and evolving quickly, educational technologies are still not being applied sufficiently, mostly for reasons of lack of technology budget and IT investment, and technical support. Other issues that have affected their integration in teaching and learning are inadequate computing and ICT infrastructure, lack of teacher and students skills in utilizing the educational technologies, low internet bandwidth and poor connection, epileptic power supply to operate the educational technologies and 
imminent lack of maintenance culture on the tools. In view of the forgoing, the research work will examine the integration of educational technologies for teaching and learning in the post covid 19 era: A case of tertiary institutions in Imo State. Specifically, the study has posed the following research questions:

i. What are the available educational technologies for teaching and learning in tertiary institutions in Imo State?

ii. What are the educational technologies that educators integrate in their teaching and learning in the post covid 19 era?

iii. What are the challenges to the integration of educational technologies for teaching and learning by educators in the post covid 19 era?

iv. What are the solutions to the challenges to the integration of educational technologies for teaching and learning by educators in the post covid 19 era?

\section{Educational Technologies}

Educational technologies are any learning tools, connected systems or applications that are projected, applied or integrated in a learning environment for the purpose of enhancing teaching and learning. According to Stošić (2015) educational technology is a systematic and organized process of applying modern technology to improve the quality of education (efficiency, optimal, true, etc.). Stošić further sees it as a systematic way of conceptualizing the execution and evaluation of the educational process, i. e. learning and teaching and help with the application of modern educational teaching techniques. It includes instructional materials, methods and organization of work and relationships, i.e. the behavior of all participants in the educational process. Definition of educational technology according to AECT (The Association for Education Communications \& Technology) is the study and ethics of practice to facilitate learning and improve performance by creating, using, and managing appropriate technological processes and resources (Molenda, 2013). In the process / concept of educational technology, the task of the media or tool is not only to communicate the relationship between the source (instructor) and the recipient (the student), but more than that it is an integral part and has interrelationships between components with one another, mutually interact and influence each other (Sudarsana, 2013). Educational technologies are learning tools such as teleconferencing, computer, Internet, projectors, computerbased learning softwares, Moodle, LMS (Black board), PowerPoint, smart boards, whiteboard and some collaborative tools, such as Microsoft Groove and Dropbox, which provide solutions to instructional problems and also improves the effectiveness and efficiency of learning in educational contexts

\section{Integration of educational technologies for teaching and learning in a post Covid 19 era}

Over the years, there has been the call for integration of ICT and educational technologies in the teaching and learning process in educational institutions. This is because of the widespread belief that ET can enhance teaching and learning practices (Higgins, 2003), and create an "ideal" learning environment (Marshall, 2002). Regrettably, they have not been applied fully in schools as the manual or traditional teaching and learning methods are still highly prevalent in the school system. However, with the closedown of schools due to the Covid 19 pandemic, there has been an increased shift of many educational institutions to the integration of educational technologies in their learning process. This massive move to the use of educational technologies is connected with the view that if any future circumstance occurs that will warrant closedown of schools; these tools would have been greatly utilized and domesticated by majority of educational institutions.

With a view of the post Covid 19 realities, appropriate educational technologies in learning must be assessed 
based on its potential to meet new educational goals that will be developed due to the outburst of Covid 19. The main potential of educational technology in the post Covid 19 pandemic is to support creativity and innovativeness, thus, integration of educational technologies will creates opportunities for learners to develop their cognitive, critical thinking, information reasoning and communication skills (Chigona and Chigona, 2010). With the integration of educational technology, students can independently progress in mastering teaching materials, to choose the pace of work, to repeat the material that is not sufficiently clear, that after tests performed immediately get results and track their progress (AlAmmary, 2012). Interactive multimedia content if used as a post Covid 19 teaching and learning tool will provide a great advantage of modern learning over traditional learning.

With the integration of educational technology in the post Covid 19 era, it can profitably empower teachers and learners, transforming teaching and learning processes from being highly teacher dominated to student centred (Higgins, 2003), as there will be effective feedback between the teacher and the student. Lowther, Inan, Ross and Strahl (2012) stated that educational technology has not yet taken its place, in spite of their recommendations. Also, Leu, O'Byrne, Zawlinski, McVerry and Everett-Cacopardo (2009) found that learners in poorer areas very rarely use the Internet as a learning tool. The innovation brought about by the ICT has seen today's learners use modern technical equipment from an early age (Gutnik, Robb, Takeuchi \& Kotler, 2011; Rideout 2011) so that their learning with the educational technologies in the post Covid 19 era will not be a problem.

The integration of educational technologies will become an integral part of both the teaching and learning process in the post Covid 19 era and they will have the greatest impact on improving student learning and achieving measurable educational objectives. Previous study by Greenhow, Robelia and Hughes (2009) shows that more students use modern technical equipment and Lee, Lim and Grabowski (2008) found that these educational technologies have an influence on the cognitive processes of learners. The task for educators in educational institutions is to ensure that their integration of educational technologies are primarily focused on the educational value of the tools and applications they use, their level of skills in its usage, and how to transfer technological knowledge and competencies on the students.

A critical factor in the successful implementation of educational technologies in tertiary institutions has been identified as the competence of the teachers to know why, when and how best to implement educational technologies (Krumsvik, 2014; Lindberg \& Olofsson, 2012). The integration of educational technologies by teachers is however a complex process influenced by many factors both extrinsic and intrinsic (Drent \& Meelissen, 2008; Price, 2014). The integration of educational technologies in the post Covid 19 era must be structurally related in a hierarchy of inclusiveness, ranging from information transmission to facilitating learning through conceptual change. The integration of educational technologies must have contentfocused teaching which is likely to manifest itself in technology use. Comparatively, a learning-focused use of technology will allow students to demonstrate their understanding of a topic (Kirkwood \& Price, 2013). Conclusively, Kreber and Kanuka (2013) posited that it is important for teachers to perceive and use technology as an integral part of a student-centred approach to teaching if enhanced learning outcomes are to be achieved.

\section{METHODOLOGY}

The study adopted survey research design. A sample population of 10 educators each was drawn from the department of Library and Information Science of Federal 
Ojukwu, Njideka-Nwawih Charlotte et.al. Educational technology for teaching and learning in the post Covid19 era: a case study of tertiary institutions in Imo state, Nigeria.

Polytechnic Nekede Owerri (FPNO) and Imo State University Owerri (IMSU). Observation checklist was used to collect data for research question 1 while questionnaire was used to collect data for research questions 2 to 4 . The reliability coefficient of the instrument was established using Richard Kudarson 21. A reliability coefficient of 0.86 was obtained from the analysis and was considered highly reliable for the study. A total of 20 copies of each set of the instruments were distributed in the two tertiary institutions out of which 15 completed copies were found usable. Data collected were analyzed using frequencies, percentages and mean scores. The instrument was structured on a four point scale. The decision rule for the mean score is 2.50 .

\section{Analysis of Findings}

Table 1: Checklist on the available educational technologies for teaching and learning in tertiary institutions in Imo State

\begin{tabular}{|l|l|l|l|l|l|}
\hline \multirow{2}{*}{ S/NO } & Available educational technologies & \multicolumn{2}{|c|}{ Tertiary Institutions } & \multirow{2}{*}{ Total } & \multirow{2}{*}{ \% of total availability } \\
\cline { 3 - 4 } & & FPNO & IMSU & & \\
\hline 1 & Computer & 1 & 1 & 2 & 100 \\
\hline 2 & Microsoft Groove & 0 & 0 & 0 & 0 \\
\hline 3 & Dropbox & 0 & 0 & 0 & 0 \\
\hline 4 & Whiteboard & 1 & 1 & 2 & 100 \\
\hline 5 & Smart boards & 1 & 0 & 1 & 50 \\
\hline 6 & PowerPoint equipment & 1 & 1 & 2 & 100 \\
\hline 7 & Social media tools & 1 & 1 & 2 & 100 \\
\hline 8 & Moodle & 1 & 1 & 2 & 100 \\
\hline 9 & Internet & 1 & 1 & 2 & 100 \\
\hline 10 & Projectors & 1 & 1 & 2 & 100 \\
\hline 11 & Computer-based learning softwares & 1 & 1 & 2 & 100 \\
\hline 12 & Teleconferencing & 0 & 0 & 0 & 0 \\
\hline 13 & Audio or video tape & 1 & 1 & 2 & 100 \\
\hline 14 & CD-ROM & 1 & 1 & 2 & 100 \\
\hline 15 & Satellite TV & 0 & 0 & 0 & 0 \\
\hline 16 & Local intranet/extranet & 1 & 1 & 2 & 100 \\
\hline 17 & Tablet or smartphone & 1 & 1 & 2 & 100 \\
\hline 18 & Interactive TV & 0 & 0 & 0 & 0 \\
\hline 19 & Camcorders & 0 & 0 & 0 & 0 \\
\hline 20 & Digital cameras & 1 & 1 & 2 & 100 \\
\hline 21 & Scanners & 1 & 1 & 2 & 100 \\
\hline 22 & Audio and video conferencing & 2 & 100 \\
\hline
\end{tabular}

Table 2: Mean ratings on the educational technologies that educators integrate in their teaching and learning in the post covid 19 era

KEYS: Strongly Agreed $(S A)=4 ;$ Agree $(A)=3 ;$ Disagreed $(D)=2 ;$ Strongly disagree $(S D)=1$.
\begin{tabular}{|l|l|l|l|}
\hline S/NO & ET that educators integrate in their teaching and learning & Mean & Decision \\
\hline 1 & Computer & 3.20 & Agree \\
\hline 2 & Microsoft Groove & 2.01 & Disagree \\
\hline 3 & Dropbox & 2.09 & Disagree \\
\hline 4 & Whiteboard & 2.72 & Agree \\
\hline 5 & Smart boards & 2.84 & Agree \\
\hline 6 & PowerPoint & 3.03 & Agree \\
\hline 7 & Social media tools & 3.11 & Agree \\
\hline 8 & Moodle & 2.61 & Agree \\
\hline 9 & Internet & 3.12 & Agree \\
\hline 10 & Projectors & 3.05 & Agree \\
\hline 11 & Computer-based learning softwares & 2.66 & Agree \\
\hline 12 & Teleconferencing & 2.31 & Disagree \\
\hline 13 & Audio or video tape & 3.03 & Agree \\
\hline 14 & CD-ROM & 3.06 & Agree \\
\hline 15 & Satellite TV & 2.14 & Disagree \\
\hline 16 & Local intranet/extranet & 2.75 & Agree \\
\hline 17 & Tablet or smartphone & 3.18 & Agree \\
\hline 18 & Interactive TV & 2.27 & Disagree \\
\hline 19 & Camcorders & 1.63 & Disagree \\
\hline 20 & Digital cameras & 2.91 & Agree \\
\hline 21 & Scanners & 2.81 & Agree \\
\hline 22 & Audio and video conferencing & 2.70 & Agree \\
\hline
\end{tabular}


In Table 1, the analysis of the checklist on the available educational technologies for teaching and learning in tertiary institutions in Imo State shows that the schools have computers, whiteboards, smart boards, powerpoint equipment, social media tools, moodle, internet, projectors, computer-based learning softwares, audio or video tape, CD-ROM, local intranet/extranet, tablet or smartphone, digital cameras, scanners, and audio and video conferencing. However, the schools do not have microsoft groove, dropbox, teleconferencing, satellite $\mathrm{TV}$, interactive $\mathrm{TV}$, and camcorders.
In Table 2, the educational technologies that educators integrate in their teaching and learning in the post covid 19 era in tertiary institutions in Imo State are computers, whiteboards, smart boards, powerpoint equipment, social media tools, moodle, internet, projectors, computerbased learning softwares, audio or video tape, CD-ROM, local intranet/extranet, tablet or smartphone, digital cameras, scanners, and audio and video conferencing. However, the educators do not integrate microsoft groove, dropbox, teleconferencing, satellite TV, interactive $\mathrm{TV}$, and camcorders in their teaching.

Table 3: Mean ratings on the challenges to the integration of educational technologies for teaching and learning by educators in the post covid 19 era

\begin{tabular}{|l|l|l|l|}
\hline S/NO & Challenges to the integration of ET for teaching and learning & Mean & Decision \\
\hline 1 & Inadequate funding of tertiary institutions & 2.74 & Agree \\
\hline 2 & Insufficiency of ET/ICT infrastructure in schools & 2.82 & Agree \\
\hline 3 & Poor confidence of educators in the use of ET & 3.05 & Agree \\
\hline 4 & Erratic power supply to use ET & 3.12 & Agree \\
\hline 5 & Poor maintenance culture on ET & 2.60 & Agree \\
\hline 6 & High cost of ET & 3.15 & Agree \\
\hline 7 & Low usage literacy of ET by students & 3.02 & Agree \\
\hline 8 & Poor ICT policy in the use of ICT/ET & 2.70 & Agree \\
\hline 9 & Insufficient budget for procurement of ET facilities & 2.82 & Agree \\
\hline 10 & Lack of technical support & 2.51 & Agree \\
\hline 11 & Poor quality of the ET resources & 3.10 & Agree \\
\hline 12 & Lack of incentive to change educator's readiness to adopt and use ET & 3.00 & Agree \\
\hline 13 & Low students' acceptance and attitude to the use of ET & 2.90 & Agree \\
\hline 14 & Poor training of educators in use of ET & 2.85 & Agree \\
\hline 15 & lack of policy and planning of using the ET & 2.71 & Agree \\
\hline 16 & Poor instructor's attitude towards use of ET & 3.02 & Agree \\
\hline 17 & Poor attitude and support of administrators towards the adoption of ET & 3.07 & Agree \\
\hline
\end{tabular}

In Table 3, the challenges to the integration of educational technologies for teaching and learning by educators in the post covid 19 era in tertiary institutions in Imo State are inadequate funding of tertiary institutions, insufficiency of ET/ICT infrastructure in schools, poor confidence of educators in the use of ET, erratic power supply to use ET, poor maintenance culture on ET, high cost of ET, low usage literacy of ET by students, poor ICT policy in the use of ICT/ET, insufficient budget for procurement of ET facilities, lack of technical support, poor quality of the ET resources, lack of incentive to change educator's readiness to adopt and use ET, low students' acceptance and attitude to the use of ET, poor training of educators in use of ET, lack of policy and planning of using the ET, poor instructor's attitude towards use of ET, and poor attitude and support of administrators towards the adoption of ET.

In Table 4, the solutions to the challenges in the integration of educational technologies for teaching and learning by educators in the post covid 19 era in tertiary institutions in Imo State are adequate funding of tertiary institutions, sufficiency of ET/ICT infrastructure in schools, confidence of educators in the use of ET, good power supply to use ET, good maintenance culture on ET, subsidized cost of ET, training students on usage of ET, effective ICT policy in the use of ICT/ET, sufficient budget for procurement of ET facilities, adequate technical support, good quality of the ET resources, provision of incentive to change educator's readiness to 
adopt ET, students' acceptance and attitude to the use of ET, regular training of educators in use of ET, good policy and planning of using the ET, enhanced instructor's attitude towards use of ET, and positive attitude/support of administrators towards the adoption of ET.

Table 4: Mean ratings on the solutions to the challenges to the integration of educational technologies for teaching and learning by educators in the post covid 19 era

\begin{tabular}{|l|l|l|l|}
\hline S/NO & Solutions to the challenges of integrating ET for teaching and learning & Mean & Decision \\
\hline 1 & Adequate funding of tertiary institutions & 3.05 & Agree \\
\hline 2 & Sufficiency of ET/ICT infrastructure in schools & 3.02 & Agree \\
\hline 3 & Confidence of educators in the use of ET & 2.95 & Agree \\
\hline 4 & Good power supply to use ET & 2.88 & Agree \\
\hline 5 & Good maintenance culture on ET & 2.78 & Agree \\
\hline 6 & Subsidized cost of ET & 3.12 & Agree \\
\hline 7 & Training students on usage of ET & 3.17 & Agree \\
\hline 8 & Effective ICT policy & 2.94 & Agree \\
\hline 9 & Sufficient budget for procurement of ET facilities & 2.72 & Agree \\
\hline 10 & Adequate technical support & 3.01 & Agree \\
\hline 11 & Good quality of the ET resources & 3.02 & Agree \\
\hline 12 & Provision of incentive to change educator's readiness to adopt ET & 2.80 & Agree \\
\hline 13 & Students' acceptance and attitude to the use of ET & 3.05 & Agree \\
\hline 14 & Regular training of educators in use of ET & 3.12 & Agree \\
\hline 15 & Good policy and planning in using the ET & 2.80 & Agree \\
\hline 16 & Enhanced instructor's attitude towards use of ET & 2.92 & Agree \\
\hline 17 & Positive attitude/support of administrators towards the adoption of ET & 2.71 & Agree \\
\hline
\end{tabular}

\section{CONCLUSION}

The outburst of Covid 19 pandemic has provided educators with the opportunity to adopt educational technologies for teaching and learning in the post Covid 19 era. Integrating educational technologies in tertiary institutions will improve digital education and as well enable students to continue their learning activities. Integrating educational technologies and other elearning platforms will enable educators to be abreast with the rapid emergence of new technologies, thus making online, blended and remote learning a necessity in their instructional delivery. Notwithstanding that the Covid 19 has presented undue challenges to the delivery of effective teaching and learning in tertiary institutions, the integration of educational technologies will promote cross collaboration between instructional, content, and technological skills. In essence, educational technologies if applied in teaching and learning can serve as a potent force in transforming the educational landscape as they have proved to be very useful when optimized for teaching and learning activities. In addition, educational technologies can also make students more active, creative, and increase their interest in learning. The application of technology in post Covid 19 era in tertiary institutions will make the learning process in general more efficient, more effective and have a positive impact.

\section{Recommendations} provided:

The following recommendations are

- Adequate training on the use of educational technologies should be provided for educators and their students to improve their teaching and learning

- There should be adequacy of educational technological tools and resources to support teaching and learning activities in the post Covid 19 era

- Educational institutions should be properly funded to enable them build up relevant systems that will drive the integration of educational technologies for their institutions

- The existing ICT policy should be reviewed to favor tertiary institutions and students towards acquiring relevant ICT skills to utilize the educational technologies

Acknowledgement: None 
Conflict of Interest: None

\section{Source of Funding: None}

\section{REFERENCES}

1. Agim, EC, Oraekwe, N.I, Chivuzo, CC \& Emenari, BC (2020) Librarians' use of social media in disseminating health information on COVID-19. International Journal of Research and Review, 7(7): 443-454.

2. AlAmmary, J. (2012) Educational Technology: A way to enhance student achievement at the University of Bahrain. Procedia - Social and Behavioral Sciences 55 (2) $248-257$

3. Ali, W. (2020) Online and Remote Learning in Higher Education Institutes : A Necessity in light of COVID 19 Pandemic. Higher Education Studies; 10, 3; p.16-25

4. Chigona, A \& Chigona, W (2010) An investigation of factors affecting the use of ICT for teaching in Western Cape Town, the 18th European Conference on Information System-ECIS 2010 proceeding, Paper 6

5. Drent, M., \& Meelissen, M. (2008). Which factors obstruct or stimulate teacher educators to use ICT innovatively? Computers \& Education, 51(1), 187-199.

6. Greenhow, C., Robelia, B., \& Hughes, J. E. (2009). Web 2.0 and classroom research: What path should we take now? Educational Researcher, 38(4), 246-259.

7. Gutnick, A.L., M. Robb, L. Takeuchi, \& J. Kotler. (2011). Always Connected: The New Digital Media Habits of Young Children. New York: The Joan Ganz Cooney Center at Sesame Workshop. Retrieved from www.ictliteracy.info/rf.pdf/jgcc_alwaysco nnected.pdf

8. Higgins, S. (2003), Partez-Vous Mathematics? In Enhancing primary mathematics teaching and learning, Thompson, I, Buckingham: Open University press

9. Kirkwood, A., \& Price, L. (2013). Examining some assumptions and limitations of research on the effects of emerging technologies for teaching and learning in higher education. British Journal of Educational Technology, 44(4), 536-543.

10. Kreber, C., \& Kanuka, H. (2013). The scholarship of teaching and learning and the online classroom. Canadian Journal of University Continuing Education, 32(2).

11. Krumsvik, R. J. (2014). Teacher educators' digital competence. Scandinavian Journal of Educational Research, 58(3), 269-280

12. Lee, H. W., Lim, K. Y., \& Grabowski, B. L. (2008). Generative learning: Principles and implications for making meaning. In M. J. Spector, D. M. Merrill, J. van Merrienboer \& M. P. Driscoll (Eds.), Handbook of research and educational communications and technology (3rd ed.). New York, NY: Taylor \& Francis Group.

13. Leu, D. J., O’Byrne, W. I., Zawlinski, L., McVerry, G., \& Everett-Cacopardo, H. (2009). Expanding the new literacies conversation. Educational Researcher, 38(4), 264-269.

14. Lindberg, O., \& Olofsson, A. (2012). Sustaining a Professional Dimension in the Use of Educational Technology in European Higher Educational Practices. Educational Technology, 52(2), 34-38.

15. Lowther, D. L., Inan, F. A., Ross, S. M., \& Strahl, J. D. (2012). Do one-to-one initiatives bridge the way to 21 st century knowledge and skills?. Journal of Educational Computing Research, 46(1), 1-30.

16. Marshall, D. (2002), Learning with Technology: Evidence that technology can and does support learning. San Diego CA: Cable in classroom

17. Molenda J, (2013) Educational Technology: A Definition with Commentary. USA: Taylor \& Francis Group, LCC.

18. Ngakan P.P (2016) Membangun Karakter dengan Keutamaan Bhagavad Gita. Jakarta: Media Hindu.

19. Price, L. (2014). Modelling factors for predicting student learning outcomes in higher education. In J. R. V. D. E. D. Gibjels (Ed.), Learning patterns in higher education in the 21 st century: dimensions 
Ojukwu, Njideka-Nwawih Charlotte et.al. Educational technology for teaching and learning in the post Covid19 era: a case study of tertiary institutions in Imo state, Nigeria.

and research perspectives (pp. pp56-77): Routledge.

20. Richey, R.C. (2008) Reflections on the 2008 AECT Definitions of the Field. TechTrends, 52, 1, pp. 24-25

21. Rideout, V. (2011). Zero to Eight: Children's Media Use in America. San Francisco, CA: Common Sense Media. Retrieved from www.commonsensemedia. $\mathrm{org} / \mathrm{sites} /$ default/files/research/zerotoeight final2011.Pdf

22. Stošić, L. (2015) The importance of educational technology in teaching. International Journal of Cognitive
Research in Science, Engineering and Education (IJCRSEE), 3 (1), P.111-114

23. Sudarsana I K, (2013) Pengaruh Model Pembelajaran Kooperatif Tipe J. Penjaminan Mutu

How to cite this article: Ojukwu, NjidekaNwawih Charlotte, Chukwuyere AE, Catherine A. Educational technology for teaching and learning in the post Covid-19 era: a case study of tertiary institutions in Imo state, Nigeria. International Journal of Research and Review. 2021; 8(7): 90-98. DOI: https://doi.org/10.52403/ijrr.20210713 